\title{
VIENT DE PARAITRE
}

JACQUES, FRANCIS. Difference and Subjectivity. Translated by Andrew Rothwell. New Haven, Ct,: Yale University Press, 1991. ISBN 04830-0. 384 pp. \$32,00.

"First published in France in 1982 and now available in an English translation, this prize-winning book investigates the question of human subjectivity. In lucid prose, . Francis Jacques shows that this question, far from becoming outmoded or irrelevant, remains of central significance for philosophy and the social sciences.

Jacques takes issues with two commonly held philosophicalviews about the self: that the subject really doesn't exist at all, and that the relationship between the subject and others is not important. Jacques develops a new relational model of the subject; personal identity, he says, is largely defined in the course of communicating with others. And the self, or subject, must not only identify both parties to the conversation ('you' and 'me'), but also the absent third party ('him' or 'her').

Difference and Subjectivity is the first book by this important French philosopher to be translated into English."

LYOTARD, JEAN-FRANÇOIS. Heidegger and "the jews." Translated by Andreas Michel and Mark S. Roberts. Introduced by David Carroll. Minneapolis: University of Minnesota Press, 1990, ISBN 0-8166-1857-7. 144 pp. \$12.95.

"Jean-François Lyotard's contribution to the debate surrounding Heidegger's ties to Nazism, Heidegger and 'the jews,' is a marked departure from the standard fare. In the first of the wo interrelated essays, "the jews," Lyotard establishes the theme of the text, placing "the jews" in lower case, plural, and in quotation marks to represent the outsiders, the non-conformists, blacks, homeless, Arabs, etc. - and the Jews; as an alien and dangerous disruption, they represent an "other" to be excised from the West's dream of unbound fulfillment and development. In "Heidegger," the second essay, Lyotard sets a number 